\title{
Lipase-Mediated Dynamic Kinetic Resolution of 1-Phenylethanol Using Niobium Salts as Racemization Agents
}

\author{
Vanessa M. Higa, ${ }^{\circledR a}$ Willian S. Rocha, ${ }^{b}$ Mirela Inês de Sairre ${ }^{a}$ and Álvaro T. Omori ${ }^{\circledR * a}$ \\ ${ }^{a}$ Centro de Ciências Naturais e Humanas, Universidade Federal do ABC, 09210-580 Santo André-SP, Brazil \\ ${ }^{b}$ Departamento de Química Orgânica, Instituto de Química, Universidade Federal Rural do Rio de Janeiro, \\ 23890-000 Rio de Janeiro-RJ, Brazil
}

\begin{abstract}
In this work, a racemization method of $(S)$-1-phenylethanol by niobium salts was developed. Among the salts available, the niobium phosphate hydrate $\left(\mathrm{NbOPO}_{4} \cdot \mathrm{nH}_{2} \mathrm{O}\right)$ reduced the enantiomeric excess $(e e)$ of the chiral alcohol from 95 to $0 \%$ after $24 \mathrm{~h}$ at $60{ }^{\circ} \mathrm{C}$ in toluene. This new racemization agent was combined with a lipase (CALB) in order to achieve a chemoenzymatic dynamic kinetic resolution (DKR). Experiments demonstrated that the DKR process is feasible and the corresponding $(R)-1$-phenylethyl acetate was obtained with $92 \%$ conversion and $85 \%$ ee.
\end{abstract}

Keywords: niobium, dynamic kinetic resolution, biocatalysis, racemization agent

\section{Introduction}

Enantiomerically enriched alcohols are important building blocks in the synthesis of several chiral biologically active compounds for pharmaceuticals, agrochemicals, food products. ${ }^{1}$ In the literature, the chromatographic separation of racemates, ${ }^{2}$ the chemo- and biocatalytic stereoselective reduction from ketones ${ }^{3}$ and the kinetic resolution $(\mathrm{KR})^{4}$ of secondary alcohols are examples of methodologies that have been explored for their preparation.

Among the biocatalytic methods to obtain such chiral secondary alcohols, the enzymatic KR is one of the most used methods. ${ }^{5}$ From a synthetic point of view, the factors that make the resolution quite attractive are the availability of enzymes (hydrolases), the possibility of reaction in organic media and the high rates of selectivity and activity towards a wide range of substrates. The kinetic resolution of racemic secondary alcohols in organic media is promoted through an enzyme-catalyzed enantioselective acylation of one enantiomer of the racemic mixture in the presence of an acyl donor. ${ }^{6}$

Lipases are the most used biocatalysts in this transesterification reaction. ${ }^{7,8}$ The ester formed is optically active which can be hydrolyzed to the enantiopure alcohol. However, the main disadvantage of kinetic resolution is the maximum conversion of $50 \%$ since one of the enantiomers is reacted more quickly than the other. In order to circumvent the yield issue, the addition of a racemization

*e-mail: alvaro.omori@ufabc.edu.br agent in the resolution is an attractive method. This process is called dynamic kinetic resolution (DKR) and combines the enzyme-catalyzed kinetic resolution (KR) with the in situ racemization, providing the product as a single enantiomer in up to $100 \%$ yield (Scheme 1). ${ }^{9}$

The racemization agents have the function of racemize the chiral unreacted reagent and are extensively investigated. ${ }^{2}$ In the review article by Verho and Bäckvall, ${ }^{5}$ there are examples of metal complexes of $\mathrm{Pd}, \mathrm{Rh}, \mathrm{Ir}, \mathrm{Ru}$ and $\mathrm{V}$ that have already been tested on various secondary alcohols. Metal salts have also shown the ability to racemize chiral alcohols. $\mathrm{VOSO}_{4}$, for example, has been used successfully in combination with the enzyme CALB in the DKR of some secondary alcohols..$^{10}$ According to the authors, the racemization mechanism using vanadium salts is through the formation of benzyl carbocation, differently from the catalytic cycle of oxidation and reduction (e.g., the Shvo catalyst). ${ }^{3}$ A disadvantage of most commercial racemization agents is their high cost, making their availability difficult. The Shvo catalyst, ${ }^{11}$ for example, is one of the most wellknown catalysts used in racemization reactions, it costs around $\mathrm{R} \$ 4.106,00$ per 500 milligrams. ${ }^{12}$ In addition, many of these racemization catalysts need strong basic conditions or high heating to be activated, which can be considered a difficulty to be faced, considering that these conditions can inhibit enzymatic activity. ${ }^{2}$ In the case of $\mathrm{VOSO}_{4}$, dynamic kinetic resolution was only possible with the use of long chain esters as a transesterification agent and at relatively high temperatures $\left(80{ }^{\circ} \mathrm{C}\right) .^{3}$ Despite several reports in literature on DKR, there are still challenges to overcome 


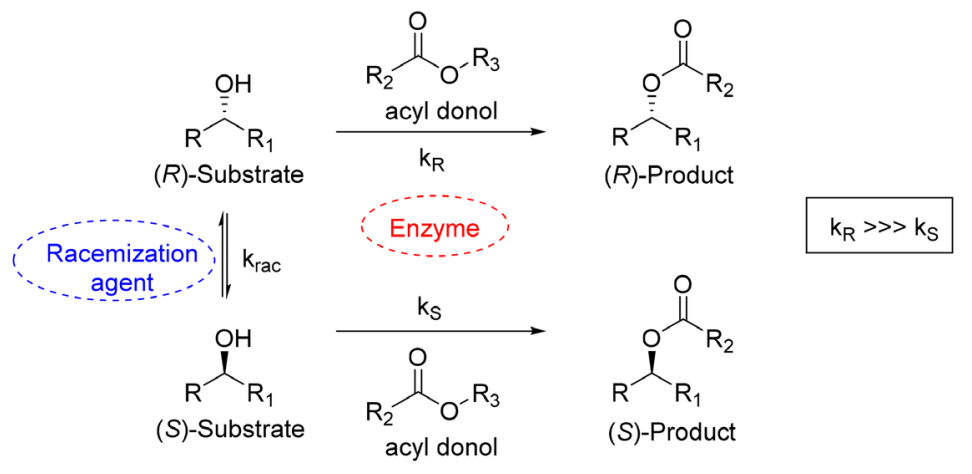

Scheme 1. Dynamic kinetic resolution.

in this field such as compatibility of racemization agents with enzymes and environmental issues, high cost and the harsh conditions which can be harmful to enzymes.

A metal that has aroused local interest is niobium, since Brazil has $98 \%$ of the world's reserve of this metal. ${ }^{13}$ The niobium compounds have several applications in various organic reactions and therefore should not be overlooked. ${ }^{14}$ The most commonly used niobium compound as efficient Lewis acid is niobium pentachloride $\left(\mathrm{NbCl}_{5}\right)$. A variety of applications of $\mathrm{NbCl}_{5}$ in organic synthesis have been reported, for example, in Diels-Alder reactions, multicomponent reactions (MCR), one-pot reactions, among others. ${ }^{15,16}$ Furthermore, the niobium oxide salts (NbOX) are also interesting for synthetic purposes. For instance, niobium pentoxide $\left(\mathrm{Nb}_{2} \mathrm{O}_{5}\right)$ is considered a useful catalyst for oxidation and dehydration reactions, rearrangements and photocatalysis. ${ }^{16}$ Niobium phosphate $\left(\mathrm{NbOPO}_{4}\right)$ catalyzes esterification reactions, ${ }^{17}$ the synthesis of quinoline derivatives ${ }^{18}$ and lactic acid. ${ }^{19}$ The use of ammonium niobium oxalate is more recent and has proved to be an efficient catalyst for the synthesis of 2-arylbenzothiazoles and 3-aryl- $2 \mathrm{H}$-benzo[ $b]$ $[1,4]$ benzoxazin-2-ones, ${ }^{20}$ as well as for the synthesis of 3-arylquinoxalin-2(1H)-ones. ${ }^{21}$

In a comparative way, still regarding the use of vanadium salts as a racemization agent, we believe that the use of niobium salts could play the same role. According to the literature, there are similarities in terms of oxophilicity ${ }^{22}$ and acidity (already mentioned use as Lewis acid). Also, there are precedents that the mechanism of formation of benzyl carbocation seen with vanadium salts, could happen with niobium salts. Yadav et al. ${ }^{23}$ reported the nucleophilic substitution reactions of benzylic alcohols catalyzed by $\mathrm{NbCl}_{5}$, probably by a carbocation mechanism. To the best of our knowledge, there is no report on the use of these $\mathrm{Nb}$ compounds in the racemization process in DKR. Thus, this work reports the dynamic kinetic resolution of secondary alcohols using niobium catalyst as a racemization agent.

\section{Experimental}

General

Solvents were purchased from Synth (reagent grade, Diadema, Brazil) and used without further purification. Lipase B (CALB) from Candida antarctica lipase (Novozym-435) was purchased from Sigma-Aldrich (St. Louis, USA). Niobium salts $\left(\mathrm{NbOPO}_{4} \cdot \mathrm{nH}_{2} \mathrm{O}\right.$, $\mathrm{Nb}_{2} \mathrm{O}_{5} \cdot \mathrm{nH}_{2} \mathrm{O}, \mathrm{NbCl}_{5}$ and $\left.\mathrm{NH}_{4}\left[\mathrm{NbO}\left(\mathrm{C}_{2} \mathrm{O}_{4}\right)\left(\mathrm{H}_{2} \mathrm{O}\right) \mathrm{x}\right] \cdot \mathrm{nH}_{2} \mathrm{O}\right)$ was gently donated by Companhia Brasileira de Metalurgia e Mineração (CBMM) (Araxá, Brazil) through Prof Mirela Inês de Sairre (UFABC-CCNH). Mixing and heating of Falcon and glass tubes were made in a Thermomixer ${ }^{\circledR}$ (Eppendorf, Hamburg, Germany). Analytical thin-layer chromatography (TLC) was performed with aluminumbacked silica plates coated with a $0.25 \mathrm{~mm}$ thickness of silica gel 60 F254 (Merck, Darmstadt, Germany), exposure to vanillin or potassium permanganate solution and heating. Column chromatography separations were followed using 35-70 mm (240-400 mesh) silica gel purchased from SigmaAldrich (St. Louis, USA). Chiral gas chromatography with flame ionization detection (GC-FID) analyses were recorded on a 450-GC (Varian, Palo Alto, USA) with a Chiralsil-Dex CB $\beta$-cyclodextrin $(25 \mathrm{~m} \times 0.25 \mathrm{~mm})$ column using $\mathrm{H}_{2}$ as the carrier gas. Analysis method for chiral GC to determine the enantiomeric excess (ee) values of 1-phenylethanol was adopted from the literature, and the respective retention times are in agreement with the expected results described by Costa and Omori. ${ }^{24}$ The enantiomeric excess of 1-phenylethanol was calculated according to equation: $\left[\left(E_{1}-E_{2}\right) /\left(E_{1}+E_{2}\right)\right] \times 100$, where $E_{1}$ and $E_{2}$ are the amount of enantiomers as determined by chiral GC analyses.

\section{Synthesis of (rac)-1-phenylethanol}

Synthesis of 1-phenylethanol for GC standard was prepared by reduction of the corresponding acetophenone with sodium borohydride in methanol. To a stirred solution 
of acetophenone (13.9 mmol, $1.67 \mathrm{~g})$ in methanol $(50 \mathrm{~mL})$ at $0{ }^{\circ} \mathrm{C}$, sodium borohydride $(13.9 \mathrm{mmol}, 529 \mathrm{mg})$ was added portion wise. After $20 \mathrm{~min}$, the solvent was removed under reduced pressure and the crude product was suspended in ethyl acetate $(100 \mathrm{~mL})$. The organic phase was then washed $(3 \times 50 \mathrm{~mL})$ with saturated solution of ammonium chloride. The organic phase was dried with anhydrous $\mathrm{Na}_{2} \mathrm{SO}_{4}$, filtered and concentrated under reduced pressure. After GC analysis, the product was applied without further purification.

\section{Enzymatic kinetic resolution of 1-phenylethanol ${ }^{25}$}

To a solution of racemic 1-phenylethanol (1) $(13.5 \mathrm{mmol}$, $1.642 \mathrm{~g})$ in hexane $(80 \mathrm{~mL})$, CALB lipase $(250 \mathrm{mg})$ was added followed by a dropwise addition of vinyl acetate $(27 \mathrm{mmol}, 2.35 \mathrm{~mL})$. The reaction was kept under orbital stirring at $180 \mathrm{rpm}$ for $4 \mathrm{~h}$. After filtration, the organic phase was concentrated under reduced pressure. The crude product was purified by column chromatography using hexane/ ethyl acetate (9:1) as eluent. (R)-1-Phenylethyl acetate (2) (959 mg, isolated yield: 43\%) (S)-1-phenylethanol (679 mg, isolated yield: $41 \%$ ).

\section{General procedure for racemization of (S)-1-phenylethanol}

The corresponding niobium salt $(50 \mathrm{mg}$ ) (Tables 1 to 4) was added in a $15 \mathrm{~mL}$ Falcon tube containing alcohol (S)-1-phenylethanol $(0.24 \mathrm{mmol})$ dissolved in $6 \mathrm{~mL}$ of an appropriate solvent. The reaction was kept under stirring and heating for the time indicated (Tables 1 to 4 ). $100 \mu \mathrm{L}$ aliquots for GC analysis were collected after 3, 6 and $24 \mathrm{~h}$ of reaction and diluted with $100 \mu \mathrm{L}$ ethyl acetate in a $1.5 \mathrm{~mL}$ microtube. Chromatograms from chiral GC analysis were used to calculate conversion and enantiomeric excess (ee) values.

\section{General procedure for DKR reaction}

In a $15 \mathrm{~mL}$ glass tube with screw top cap, the lipase $(10 \mathrm{mg})$ and the niobium salt $(50 \mathrm{mg})$ were inserted into the tube separated by thin cotton layers. At the end, a solution of racemic 1-phenylethanol $(0.24 \mathrm{mmol}, 30 \mathrm{mg})$ in toluene $(6 \mathrm{~mL})$ was added followed by vinyl acetate $(1 \mathrm{mmol}, 86 \mathrm{mg})$. The tube was closed and the reaction was stirred at $700 \mathrm{rpm}$ at $60^{\circ} \mathrm{C}$. Aliquots were collected after the time indicated in the Tables 5 and 6 . Chromatograms from chiral GC analysis were used to calculate conversion and $e e$ values.

\section{Results and Discussion}

\section{Racemization reaction}

Initially, we focused on the optimization of conditions for the racemization of chiral 1-phenylethanol. For this purpose, four available niobium salts were screened for their activity with compound $\mathbf{1}$ in toluene at $60{ }^{\circ} \mathrm{C}$. The enantiomeric excesses of 1 were measured after 3 and $24 \mathrm{~h}$, and the results are summarized in Table 1.

Table 1. Racemization of (S)-1-phenylethanol (1) using Nb salts ${ }^{\mathrm{a}}$

\begin{tabular}{|c|c|c|c|c|}
\hline entry & $\mathrm{Nb}$ salt & & $\begin{array}{c}e e \text { of } \mathbf{1} \text { after } \\
3 \mathrm{~h}^{\mathrm{b}} / \%\end{array}$ & $\begin{array}{c}e e \text { of } \mathbf{1} \text { after } \\
24 \mathrm{~h}^{\mathrm{b}} / \%\end{array}$ \\
\hline 1 & none & & 96 & 94 \\
\hline 2 & $\mathrm{NbOPO}_{4} \cdot \mathrm{nH}$ & & 50 & 0 \\
\hline 3 & $\mathrm{Nb}_{2} \mathrm{O}_{5} \cdot \mathrm{nH}_{2}$ & & 96 & 94 \\
\hline 4 & $\mathrm{NbCl}_{5}$ & & 46 & $-{ }^{c}$ \\
\hline 5 & $\mathrm{NH}_{4}\left[\mathrm{NbO}\left(\mathrm{C}_{2} \mathrm{O}_{4}\right)\left(\mathrm{H}_{2}\right.\right.$ & $\left.\mathrm{O})_{\mathrm{x}}\right] \cdot \mathrm{nH}_{2} \mathrm{O}$ & 94 & 76 \\
\hline
\end{tabular}

${ }^{\mathrm{a}}(\mathrm{S})$-1-Phenylethanol $(0.24 \mathrm{mmol}), \mathrm{Nb}$ salt $(50 \mathrm{mg})$ in toluene $(6 \mathrm{~mL})$ were stirred $(700 \mathrm{rpm})$ at $60^{\circ} \mathrm{C}$; benantiomeric excess $(e e)$ was determined by chiral GC analysis; " no peaks of 1-phenylethanol was detected.

Among all $\mathrm{Nb}$ salts examined, $\mathrm{NbOPO}_{4} \cdot \mathrm{nH}_{2} \mathrm{O}$ showed the highest activity for the racemization of (S)-1-phenylethanol, giving $0 \%$ ee in $24 \mathrm{~h}$ of reaction (Table 1, entry 2). Possible byproduct formation was observed in the reaction using $\mathrm{NbCl}_{5}$. In this case, GC analysis after $24 \mathrm{~h}$ did not indicate the presence of starting material (entry 4). $\mathrm{NbCl}_{5}$ hydrolyzes rapidly in contact with moisture, releasing $\mathrm{HCl}$ in the medium which may have contributed to possible 1-phenylethanol dehydration and styrene formation. ${ }^{26}$ This screening result corroborates with the higher catalytic activity of niobium phosphates observed by Bassan et al. ${ }^{27}$ The authors also pointed that niobium phosphate presents higher concentration of Brønsted acid sites than the niobium oxide. The niobium oxide phosphate hydrate $\left(\mathrm{NbOPO}_{4} \cdot \mathrm{nH}_{2} \mathrm{O}\right)$ was then selected for further investigation.

Next, the effect of catalyst amount was evaluated in the racemization of $(S)$-1-phenylethanol catalyzed by niobium phosphate. Catalyst loadings from 10 to $200 \mathrm{mg}$ were selected and the results were presented in Table 2.

A small decrease of $e e$ was observed when $10 \mathrm{mg}$ of niobium phosphate was used (Table 2, entry 1 ) even after $24 \mathrm{~h}$ of reaction, indicating the necessity of higher quantities. The amount of $50 \mathrm{mg}$ of niobium phosphate 
Table 2. Racemization of (S)-1-phenylethanol (1) varying the quantity of $\mathrm{NbOPO}_{4} \cdot \mathrm{nH}_{2} \mathrm{O}^{\mathrm{a}}$

$\begin{array}{lcccc}\text { entry } & \begin{array}{c}\mathrm{NbOPO}_{4} \cdot \mathrm{nH}_{2} \mathrm{O} / \\ \mathrm{mg}\end{array} & \begin{array}{c}e e \text { of } \mathbf{1} \text { after } \\ 3 \mathrm{~h}^{\mathrm{b}} / \%\end{array} & e e \text { of } \mathbf{1} \text { after } \\ 6 \mathrm{~h}^{\mathrm{b}} / \% & e e \text { of } \mathbf{1} \text { after } \\ 24 \mathrm{~h}^{\mathrm{b}} / \%\end{array}$

${ }^{\mathrm{a}}(S)$-1-Phenylethanol $(0.24 \mathrm{mmol}), \mathrm{NbOPO}_{4} \cdot \mathrm{nH}_{2} \mathrm{O}$ in toluene $(6 \mathrm{~mL})$ were stirred $(700 \mathrm{rpm})$ at $60^{\circ} \mathrm{C}$; benantiomeric excess (ee) was determined by chiral GC analysis; ' ${ }^{\circ}$ unknown byproduct formation.

was chosen for further experiments. Besides the high activity with $100 \mathrm{mg}$ of catalyst (entry 3 ), the reaction mixture presented a slurry aspect which could also compromise the DKR setup. Also, above the amount of $50 \mathrm{mg}$, we noticed the formation of a byproduct after $24 \mathrm{~h}$ of reaction (entries 3 to 5 ). In order to detect possible interferences in the reaction, we observed later that this byproduct is generated from the plastic Falcon tube in contact with warm toluene. Indeed, further tests with glass tubes indicated that there is no formation of this byproduct.

Next step was to evaluate the ideal temperature for the racemization. In this case, the reaction was conducted at 20,40 and $60^{\circ} \mathrm{C}$. The results are summarized in Table 3.

Table 3. Racemization of (S)-1-phenylethanol (1) using $\mathrm{NbOPO}_{4} \cdot \mathrm{nH}_{2} \mathrm{O}$, in different temperatures ${ }^{\mathrm{a}}$

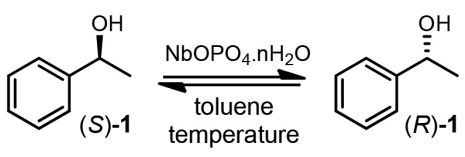

\begin{tabular}{lcccc}
\hline entry & $\begin{array}{c}\text { Temperature / } \\
{ }^{\circ} \mathrm{C}\end{array}$ & $\begin{array}{c}e e \text { of } \mathbf{1} \text { after } \\
3 \mathrm{~h}^{\mathrm{b}} / \%\end{array}$ & $\begin{array}{c}e e \text { of } \mathbf{1} \text { after } \\
6 \mathrm{~h}^{\mathrm{b}} / \%\end{array}$ & $\begin{array}{c}e e \text { of } \mathbf{1} \text { after } \\
24 \mathrm{~h}^{\mathrm{b}} / \%\end{array}$ \\
\hline 1 & 20 & $>98$ & $>98$ & $>98$ \\
2 & 40 & 96 & 96 & 86 \\
3 & 60 & 50 & 33 & 0 \\
\hline
\end{tabular}

a $(S)$-1-Phenylethanol $(0.24 \mathrm{mmol}), \mathrm{NbOPO}_{4} \cdot \mathrm{nH}_{2} \mathrm{O}(50 \mathrm{mg})$ in toluene $(6 \mathrm{~mL})$ were stirred $(700 \mathrm{rpm})$; ${ }^{\mathrm{b}}$ enantiomeric excess $(e e)$ was determined by chiral GC analysis.

The enantiomeric excess of the reaction at $60{ }^{\circ} \mathrm{C}$ (entry 3) was smaller than the reactions at 20 and $40{ }^{\circ} \mathrm{C}$ (entries 1 and 2). As expected, the heating affects the reaction kinetics and thus the temperature at $60{ }^{\circ} \mathrm{C}$ was preferred for subsequent reactions. Reactions above $60^{\circ} \mathrm{C}$ were not conducted for safety issues since the solvent used is volatile and to avoid energy waste. Besides, very high temperatures can compromise the efficiency of the lipases to be tested in DKR.

In a recent report by Milagre and co-workers, ${ }^{28}$ the $\mathrm{VOSO}_{4}$ catalyzed racemization of $(S)$-1-phenylethanol is faster at $80^{\circ} \mathrm{C}$ but a byproduct formation was also observed. They concluded that decreasing the temperature resulted in better selectivity.

The effect of the solvent was also evaluated in the racemization of $(S)$-1. Using the optimized conditions $\left(60{ }^{\circ} \mathrm{C}, 50 \mathrm{mg}\right.$ of $\left.\mathrm{NbOPO}_{4} \cdot \mathrm{nH}_{2} \mathrm{O}\right)$, five common solvents for DKR were tested (Table 4).

Table 4. Racemization of (S)-1-phenylethanol (1) using $\mathrm{NbOPO}_{4} \cdot \mathrm{nH}_{2} \mathrm{O}$, in different solvents ${ }^{\mathrm{a}}$

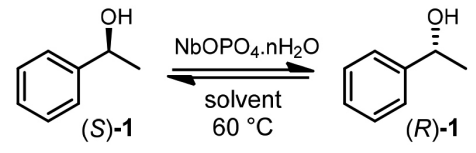

\begin{tabular}{lcccc}
\hline entry & Solvent & $\begin{array}{c}e e \text { of } \mathbf{1} \text { after } \\
3 \mathrm{~h}^{\mathrm{b}} / \%\end{array}$ & $\begin{array}{c}e e \text { of } \mathbf{1} \text { after } \\
6 \mathrm{~h}^{\mathrm{b}} / \%\end{array}$ & $\begin{array}{c}e e \text { of } \mathbf{1} \text { after } \\
24 \mathrm{~h}^{\mathrm{b}} / \%\end{array}$ \\
\hline 1 & toluene & 76 & 56 & 42 \\
2 & hexane & 88 & 73 & 71 \\
3 & $1,4-$ dioxane & $>98$ & $>98$ & $>98$ \\
4 & diethyl ether & 98 & $-^{\mathrm{c}}$ & $-^{\mathrm{c}}$ \\
5 & THF & $>98$ & $-^{\mathrm{c}}$ & $-^{\mathrm{c}}$ \\
\hline
\end{tabular}

${ }^{\mathrm{a}}(\mathrm{S})$-1-Phenylethanol $(4.8 \mu \mathrm{L})$, solvent $(1 \mathrm{~mL}), \mathrm{NbOPO}_{4} \cdot \mathrm{nH}_{2} \mathrm{O}(8 \mathrm{mg})$ were stirred $(700 \mathrm{rpm})$ at $60{ }^{\circ} \mathrm{C}$; benantiomeric excess $(e e)$ was determined by chiral GC analysis; ${ }^{\circ} e e$ not measured due to evaporation. THF: tetrahydrofuran.

The control reaction (entry 1) gave undesired high values of $e e$. We attribute this lower performance due to lower reaction scale (less than $5 \mu \mathrm{L}$ of starting material was used). Differently from toluene, the other solvents tested in this screening gave poor results. In the case of tetrahydrofuran (THF) and diethyl ether, we faced difficulties to maintain the solvent at $60^{\circ} \mathrm{C}$. Besides, based on the inertness with dioxane, we believe the oxygenated solvents are not suitable due to the oxyphilic character of niobium. Thus, we chose toluene not only because of the high boiling point but also because it provided the best performance of the deracemization reaction.

\section{DKR reaction}

With the optimized racemization conditions in hands, the next step was to provide a suitable setup for DKR using niobium phosphate as a racemization catalyst. 
CALB (Novozym-435) was the lipase of choice because of the high reproducibility and the vast literature applying this enzyme for resolution of 1-phenylethanol. ${ }^{29}$ Initial attempts for DKR reaction were carried out mixing all reagents (rac-1-phenylethanol, CALB, niobium phosphate, vinyl acetate and toluene) in a glass tube. In this case, only traces of the desired acetate were observed even after $6 \mathrm{~h}$ of reaction.

To verify a possible inhibition of the biocatalyst by the niobium salt, another experiment was carried out with the lipase and $\mathrm{NbOPO}_{4}$ in different glass flask and the reaction medium (supernatant) was transferred from time to time from one flask to another. The results are summarized in Table 5.

According to the Table 5, it is evident that the combination of both reactions (racemization and kinetic resolution) is feasible and the niobium salt is reusable. However, due to the long reaction time for racemization, it was necessary $74 \mathrm{~h}$ to achieve the desired chiral acetate $(R)-2$ in $92 \%$ of conversion and $83 \%$ ee (entry 14). This long reaction time is associated to the fact both reactions occurred separately. Nevertheless, similarly to Wuyts et al..$^{10}$ and Milagre and co-workers ${ }^{28}$ reports, this result shows a direct evidence for the necessity to physically separate the lipase and the niobium oxide phosphate hydrate.

In order to decrease the reaction time and simultaneously maintain the separation of the catalysts, a different setup was necessary. Attempts to use an inner glass tube filled with one of the catalysts capped with cotton caused leak issues. Thus, a setup similar to a fixed bed system developed by Souza and co-workers ${ }^{30}$ was adapted. In this case, both the CALB and the $\mathrm{NbOPO}_{4}$ were added separated by thin cotton layers at the bottom of a single reaction tube. The results are summarized in Table 6. Two different flasks were prepared, flasks $\mathrm{A}$ and $\mathrm{B}$, which the sequence of the CALB and $\mathrm{NbOPO}_{4}$ were alternated.

Considering the first $4 \mathrm{~h}$ of reaction, the flask $\mathrm{B}$ produced more $(R)$-1-phenylethyl acetate (2) than flask A. However, after $6 \mathrm{~h}$ the conversion to compound $\mathbf{2}$ is higher in flask A. Since the enzymatic resolution is faster than the racemization, we presume when the lipase is in the upper layer, the enzymatic resolution prevails since the enantiomeric excess of the 1-phenylethanol is relatively higher during the reaction. On the other hand, when the niobium salt is in the upper layer, the enantiomeric excess

Table 5. Chromatographic yields of DKR reaction with both catalysts separated in two glass flasks ${ }^{\mathrm{a}}$

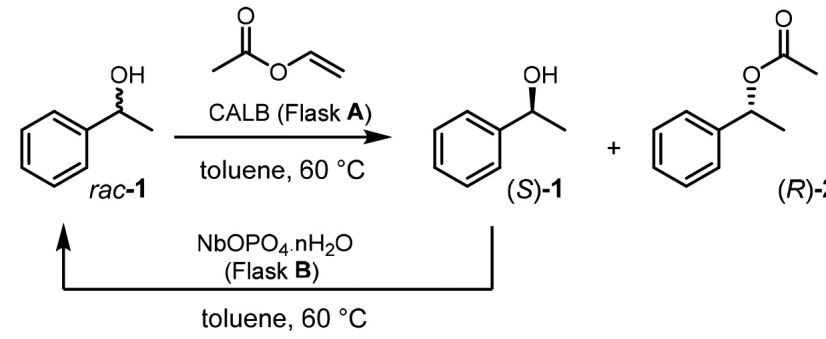

$(R)-2$

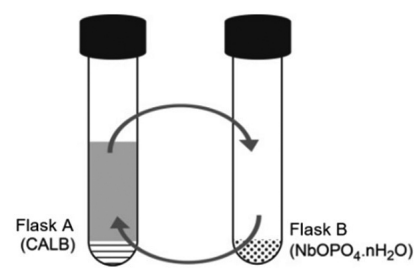

\begin{tabular}{|c|c|c|c|c|c|c|c|c|}
\hline No. & $\begin{array}{l}\text { Reaction } \\
\text { time / h }\end{array}$ & $\begin{array}{c}\text { Reaction time } \\
\text { duration in } \\
\text { flask A / h }\end{array}$ & $\begin{array}{c}\text { Reaction time } \\
\text { duration in } \\
\text { flask B / h }\end{array}$ & $(R)-1 / \%$ & $(S)-\mathbf{1} / \%$ & $(S)-2 / \%$ & $(R)-2 / \%$ & Byproduct / \% \\
\hline 1 & $0-1$ & 1 & - & 6 & 44 & 1 & 50 & - \\
\hline 2 & $1-2$ & 1 & - & 2 & 43 & 1 & 54 & - \\
\hline 3 & $2-3$ & 1 & - & - & 43 & 1 & 56 & - \\
\hline 4 & $3-6$ & 3 & - & 0 & 42 & 1 & 57 & - \\
\hline 5 & $6-24$ & - & 18 & 15 & 16 & 4 & 65 & - \\
\hline 6 & $24-25$ & 1 & - & 6 & 14 & 4 & 70 & 6 \\
\hline 7 & $25-26$ & 1 & - & 2 & 15 & 4 & 74 & 5 \\
\hline 8 & $26-27$ & 1 & - & $<1$ & 15 & 4 & 75 & 6 \\
\hline 9 & $27-48$ & - & 21 & 5 & 6 & 6 & 77 & 6 \\
\hline 10 & $48-49$ & 1 & - & 3 & 5 & 6 & 78 & 6 \\
\hline 11 & $49-50$ & 1 & - & 2 & 6 & 7 & 79 & 7 \\
\hline 12 & $50-51$ & 1 & - & 1 & 5 & 6 & 69 & 5 \\
\hline 13 & $51-72$ & - & 21 & 2.5 & 2.5 & 8 & 80 & 7 \\
\hline 14 & $72-74$ & 2 & - & 0.5 & 1.5 & 8 & 84 & 6 \\
\hline
\end{tabular}

${ }^{a}$ Reaction conditions: $(S)-1$-phenylethanol $(30 \mathrm{mg})$, toluene $(6 \mathrm{~mL}), \mathrm{NbOPO}_{4} \cdot \mathrm{nH}_{2} \mathrm{O}(50 \mathrm{mg})$, vinyl acetate $(86 \mathrm{mg}), 700 \mathrm{rpm}$ at $60{ }^{\circ} \mathrm{C}$. 
Table 6. Chromatographic yields of DKR reaction with both catalysts separated by thin cotton layer in a single bottom glass flask ${ }^{\mathrm{a}}$

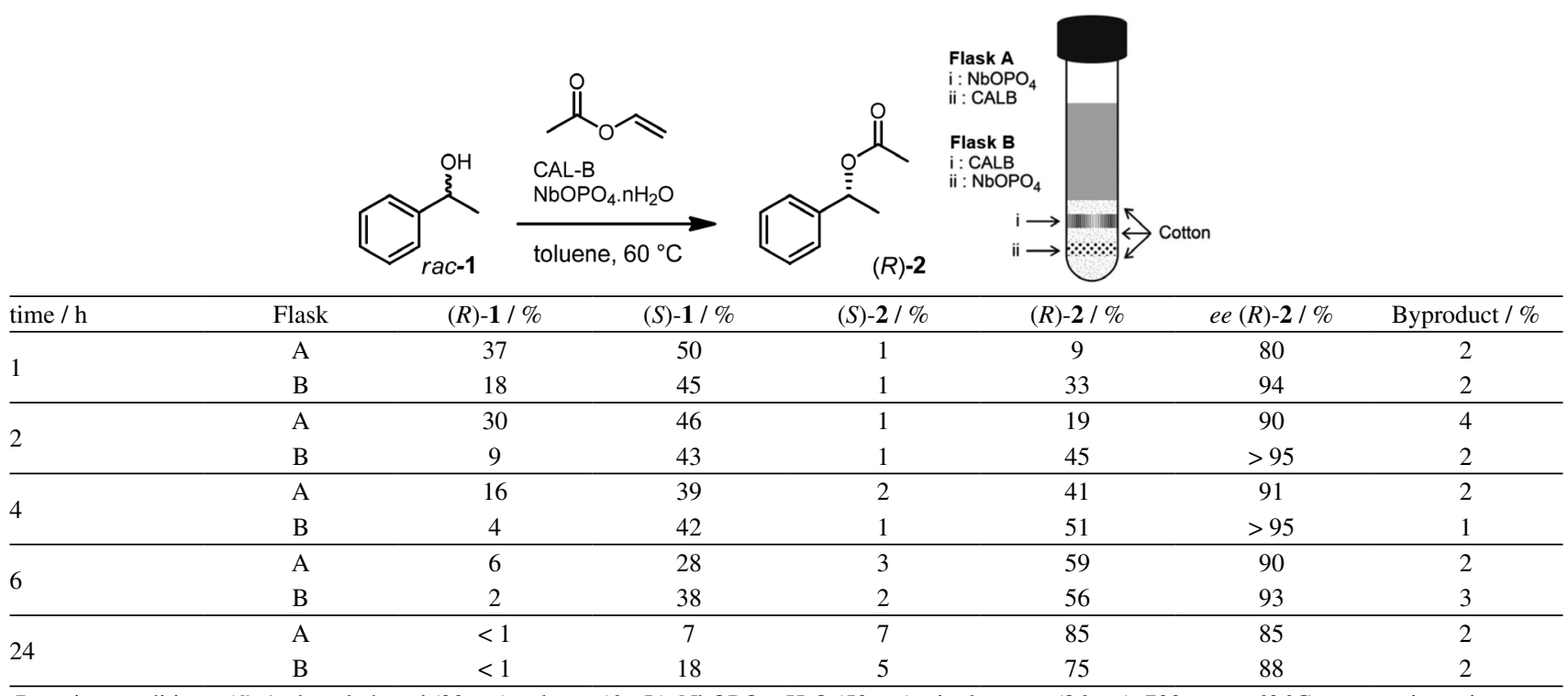

${ }^{a}$ Reaction conditions: $(S)$-1-phenylethanol $(30 \mathrm{mg})$, toluene $(6 \mathrm{~mL}), \mathrm{NbOPO}_{4} \cdot \mathrm{nH}_{2} \mathrm{O}(50 \mathrm{mg})$, vinyl acetate $(86 \mathrm{mg}), 700 \mathrm{rpm}$ at $60^{\circ} \mathrm{C} . e e$ : enantiomeric excess.

of the starting material is maintained relatively low all over the reaction.

After $24 \mathrm{~h}$, we obtained the same result to the last setup ( $92 \%$ conversion and $85 \%$ ee). Both flasks furnished the desired acetate in excellent value of conversion and good enantiomeric excess. Nonetheless, the flask A was considered a better setup because we could isolate $25 \mathrm{mg}$ of crude product after solvent removal, while for flask B, we obtained only $5 \mathrm{mg}$.

In comparison to the DKR reactions published using $\mathrm{VOSO}_{4},{ }^{10,27}$ this long time $(24 \mathrm{~h})$ presented in this work would suggests a drawback. However, the use of $\mathrm{NbOPO}_{4}$ as racemizing reagent gave better values of conversion and $e e$ with vinyl acetate as acyl donor.

\section{Conclusions}

In conclusion, this new intriguing reactivity of niobium phosphate reinforces the strategic importance of continuing to investigate this important metal, considered almost exclusive in the Brazilian territory. Similar reactivity with vanadium in racemization of $(S)$-1-phenylethanol was observed. More studies regarding the substrate tolerance, benzyl cation mechanism, acyl donor influence and scalability are ongoing in our research group.

\section{Supplementary Information}

Supplementary information (chromatograms from chiral GC analysis) is available free of charge at http://jbcs.sbq.org.br as PDF file.

\section{Acknowledgments}

We express our gratitude to FAPESP (grant ID is 2017/18007-2) for financial support.

\section{References}

1. Calcaterra, A.; D’Acquarica, I.; J. Pharm. Biomed. Anal. 2018, 147, 323; Jeschke, P.; Pest Manage. Sci. 2018, 74, 2389.

2. Shen, J.; Okamoto, Y.; Chem. Rev. 2016, 116, 1094.

3. Ni, Y.; Xu, J.-H.; Biotechnol. Adv. 2012, 30, 1279.

4. Pellissier, H.; Adv. Synth. Catal. 2011, 353, 1613.

5. Verho, O.; Bäckvall, J.-E.; J. Am. Chem. Soc. 2015, 137, 3996.

6. Chen, B.; Souza, F. Z. R.; RSC Adv. 2019, 9, 2102.

7. Gotor-Fernández, V.; Brieva, R.; Gotor, V.; J. Mol. Catal. B: Enzym. 2006, 40, 111.

8. Carvalho, A. C. L. M.; Fonseca, T. S.; de Mattos, M. C.; de Oliveira, M. D. F.; de Lemos, T. L. G.; Molinari, F.; Romano, D.; Serra, I.; Int. J. Mol. Sci. 2015, 16, 29682.

9. de Miranda, A. S.; Miranda, L. S. M.; de Souza, R. O. M. A.; Biotechnol. Adv. 2015, 33, 372.

10. Wuyts, S.; Wahlen, J.; Jacobs, P. A.; de Vos, D. E.; Green Chem. 2007, 9, 1104.

11. Conley, B. L.; Pennington-Boggio, M. K.; Boz, E.; Williams, T. J.; Chem. Rev. 2010, 110, 2294.

12. https://www.sigmaaldrich.com/catalog/product/aldrich/66828 1?lang=pt\&region=BR, accessed in March 2021.

13. Alves, A. R.; Coutinho, A. R.; Mater. Res. 2015, 18, 106.

14. Lacerda, V.; dos Santos, D. A.; da Silva, L. C.; Greco, S. J.; dos Santos, R. B.; Aldrichimica Acta 2012, 45, 19; Satoh, Y.; Obora, Y.; Eur. J. Org. Chem. 2015, 5041. 
15. Rodrigues, S. M. M.; Previdi, D.; Baviera, G. S.; Matias, A. A.; Donate, P. M.; Synthesis 2019, 51, 4498.

16. Arpini, B. H.; Bartolomeu, A. A.; Andrade, C. K. Z.; Silva-Filho, L. C.; Lacerda, V.; Curr. Org. Synth. 2015, 12, 570.

17. Rade, L. L.; Lemos, C. O. T.; Barrozo, M. A. S.; Ribas, R. M.; Monteiro, R. S.; Hori, C. E.; Renewable Energy 2019, 131, 348.

18. Jin, J.; Guidi, S.; Abada, Z.; Amara, Z.; Selva, M.; George, M. W.; Poliakoff, M.; Green Chem. 2017, 19, 2439.

19. Wang, X.; Song, Y.; Huang, C.; Wang, B.; Sustainable Energy Fuels 2018, 2, 1530.

20. Penteado, F.; Vieira, M. M.; Perin, G.; Alves, D.; Jacob, R. G.; Santi, C.; Lenardão, E. J.; Green Chem. 2016, 18, 6675.

21. Ebersol, C.; Rocha, N.; Penteado, F.; Silva, M. S.; Hartwig, D.; Lenardão, E. J.; Jacob, R. G.; Green Chem. 2019, 21, 6154.

22. Kepp, K. P.; Inorg. Chem. 2016, 55, 9461.

23. Yadav, J. S.; Bhunia, D. C.; Krishna, K. V.; Srihari, P.; Tetrahedron Lett. 2007, 48, 8306.

24. Costa, M. R.; Omori, A. T.; Food Technol. Biotechnol. 2017, 55, 231.
25. Omori, A. T.; Assis, L. F.; Andrade, L. H.; Comasseto, J. V.; Porto, A. L. M.; Tetrahedron: Asymmetry 2007, 18, 1048.

26. Bertero, N. M.; Trasarti, A. F.; Apesteguía, C. R.; Marchi, A. J.; Appl. Catal., A 2013, 458, 28.

27. Bassan, I. A. L.; Nascimento, D. R.; Gil, R. A. S. S.; Silva, M. I. P.; Moreira, C. R.; Gonzalez, W. A.; Faro Jr., A. C.; Onfroy, T.; Latchter, E. R.; Fuel Process. Technol. 2013, 106, 619.

28. Almeida, L. A.; Marcondes, T. H.; Milagre, C. D. F.; Milagre, H. M. S.; ChemCatChem 2020, 12, 2849.

29. Enantioselective acylation of 1-phenylethanol with vinyl acetate in the presence of CALB is considered a model reaction for alcohol resolution, see de los Ríos, A. P.; van Ranjwijk, F.; Sheldon, R. A.; Green Chem. 2012, 14, 1584; Mittersteiner, M.; Machado, T. M.; de Jesus, P. C.; Brondani, P. B.; Scharf, D. R.; Wendhausen Jr., R.; J. Braz. Chem. Soc. 2017, 28, 1185. 30. Miranda, A. S.; Silva, M. V. M.; Dias, F. C.; Souza, S. P.; Leão, R. A. C.; Souza, R. O. M. A.; React. Chem. Eng. 2017, 2, 375.

Submitted: April 11, 2021 Published online: June 14, 2021 